\title{
An Epidemiological Perspective on the Investigation of Genocide
}

\author{
Peter Tammes* \\ Bristol Medical School (Population Health Sciences), University of Bristol, Bristol, United Kingdom
}

Keywords: genocide, violence, mortality, Holocaust, Rwanda, epidemiology

\section{INTRODUCTION}

The World Health Assembly adopted in 1996 a resolution declaring violence a leading worldwide public health problem which was followed by the launch of a World Health Organization (WHO) campaign on violence prevention in 2002 (1). The WHO divides violence into self-directed violence, interpersonal violence, and collective violence. Related to the latter, population, and epidemiological studies investigated patterns and causes of deaths, including mass slaughtering, during and after armed conflicts such as in Darfur $(2,3)$ and Kosovo (4), but hardly for genociderelated killings such as the killing of Tutsi in Rwanda, which took place between April 7 and mid-July 1994, and the killing of Jews during World War II (WWII) or the Holocaust. Genocide is the intent of destroying in whole or in part the way of life and existence of a population group whether through acts of total war, racial extinction, or ethnic cleansing (5). This Opinion's aim is to raise attention to genocide-related deaths, an under-researched subject within the field of epidemiology and population and public health studies. It will do this by applying epidemiological measures to contribute to a better understanding of the killings during the Rwandan genocide and the Holocaust as case studies.

Often, the Rwanda genocide is compared with the Holocaust. For example, in Adam Jones' Genocide (6), a detailed and comprehensive textbook in the field of genocide studies, it is mentioned that on 20 April 1994 "between thirty-five and forty-three thousand people died in less than six hours. This was more than were killed in the Nazis' two-day slaughters of Jews outside Odessa and Kiev (at Babi Yar) in 1941, or in the largest single-day extermination spree in the gas chambers of Auschwitz-Birkenau" (p. 482). Furthermore, it refers to Prunier's statement that "the daily killing rate was at least five times that of the Nazi death camps" (p. 473). It is unclear how Prunier (7) calculated this daily killing rate ratio. Nevertheless, many refer to this ratio.

In a recent article, Stone (8) provided a sample of typical comparisons between the Holocaust and the Rwandan genocide by scholars, human-rights advocates, and policymakers stating the Rwandan genocide is the "most intense" genocide of the twentieth century, or the "most rapid genocide ever recorded." Contrary to these scholars, Stone stated that the killing of the Jews during the Holocaust was more intense than the Rwandan genocide. This statement is based on the calculation of a so-called "kill rate:" the number of victims murdered per time unit (8). Stone's study on the Nazi genocide focused on the killings during Operation Reinhard (March 1942November 1943) in Nazi-camps Belzec, Sobibor, and Treblinka-about 1.7 million Jews from Nazi German-occupied Poland or the General Government, the killing in Nazi camp Auschwitz of about 800,000 Jews from other Nazi occupied areas (March 1942-November 1944), and the widespread shooting of about 360,000 Jews in Ukraine, South Russia, and Bialystok (AugustNovember 1942). Stone identified hyper-extreme killings of Jews during August, September, and October 1942 and determined the "kill rate" for the Holocaust at 1.47 million over 100 days, or 14,700 per day. For the Rwandan genocide, Stone determined the "kill rate" at 800,000 over 100 days or 8,000 per day (8). These calculations suggest that the Holocaust "kill rate" is nearly twice as high as the Rwandan genocide "kill rate." Though, on some specific days, 
such as on some days in April 1994 (6) or on some days in October 1942 (8), daily killings were much higher; the "kill rate" calculation depends then on the selected time-period. Besides, bigger targeted groups can have a higher "kill rate" simply because of their population size.

To better understand and help to solve this controversy, we include some other measures often used in epidemiology such as mortality and survival rates. We used rough estimates as given by Prunier on the Rwanda genocide; a recent article discussed the number of Tutsi deaths in more detail but that is beyond this Opinion article (9). Similarly, we used data presented in Stone's study on the Nazi genocide (8). Since Stone's study included only victims, data available on victims and survivors of the Nazi persecution of Jews in the Netherlands (10) are included to compare their survival rates with survival rates of Tutsis in Rwanda.

\section{MEASURING DEATH FEQUENCIES FOR THE RWANDAN GENOCIDE AND THE HOLOCAUST}

\section{Mortality Rates}

Within epidemiology, measures such as the "kill rate" are referred to as an absolute rate (11). When measuring death frequency, the mortality rate is helpful when comparing groups or populations. To measure mortality rate, one must take into account the time (i.e., months) persons lived till they were killed or had survived at the end of a certain time-period (i.e., end of war or genocide), contributing to the total person-months of observations. When applying this measure to the Nazi genocide and the Rwandan genocide, the Jewish and Tutsi populations are considered closed populations-hardly any members left, or new members entered. Data presented by Stone (8) for the Nazi genocide between March 1942 and November 1944 were used to calculate an estimated mortality rate of 85 Jews per 1,000 person-months. If we only focus on August-October 1942 a 3-month period with the highest numbers of killings-though still many survivors at the end of October 1942, the mortality rate is estimated at 223 Jews per 1,000 person-months. Rough estimates of Tutsi killings in spring 1994 provided by Prunier (7) were used to calculate an estimated mortality rate of 396 Tutsi per 1,000 person-months. The Rwandan genocide mortality rate is then about 4.5 times the mortality rate of the Nazi genocide and about 1.8 times the mortality rate for the 3-month period of hyper-extreme killings in 1942.

\section{Survival Curves}

Since killings fluctuate over time, particularly in longer time periods of observation, it might be informative to calculate the cumulative proportion surviving or the survival curve. Figure 1 shows these curves based on data for the Rwandan genocide and Stone's study on the Nazi genocide; $95 \%$ confidence intervals (95\%CI) are not included in this figure since these were very small.

As the genocide faced by the population of about 930,000 Tutsis living in Rwanda lasted about 3 months with a high number of deaths from the beginning onwards, the survival curve shows a steep decrease in probability of survival until the last month resulting in a cumulative proportion surviving Tutsis in Rwanda of 0.140 (95\%CI 0.139-0.141). The killing of over 2.8 million Jews in camps Belzec, Sobibor, Treblinka, and Auschwitz and during shootings started in March 1942 and lasted 32 months. In summer and autumn of 1942, the number of deaths increased heavily resulting in a drop of the survival probability to 0.321 (95\%CI 0.320-0.321) in November 1942; a drop of about 0.68 in 9 months' time. The Jewish survival curve for JulyNovember 1942 shows nearly the same steep decrease as the Tutsis' survival curve for April-June 1994. The Jewish survival curve shows another sharp decline in May and June 1944, mainly due to increased killings in Auschwitz. There are hardly any Jewish survivors in November 1944 as nearly all deported to these four camps were killed.

Figure 1 also shows survival curves for about 117,000 Jews in the Netherlands $-83 \%$ of all Jews, split by sex (10). These curves are based on available individual-level instead of aggregated data. The data contain information on date, place and causes of death. The systematic deportation of Jews from the Netherlands started in July 1942 and to reduce immortal-time bias (12) we have excluded Jews being caught and deported before that time in a few roundups aimed to catch Jewish young adult men. Though many were killed in camps after being deported, some died in Dutch transit-camp Westerbork, in hiding or from suicide while some others are assumed to have died of natural causes in the Netherlands. This latter cause of death can be seen as a "competing risk" and these cases have been censored when calculating survival rates. The survival curves for both sexes show a similar pattern, though the survival curve for women had dropped stronger by September 1943 (survival probability: 0.363 ; 95\%CI $0.359-0.367)$ than that for men $(0.429 ; 95 \% \mathrm{CI}$ $0.425-0.433)$. Although the drop in survival for Jewish men and women identifies a period of intense deportations and killings, this drop is less steep than for Tutsis during the Rwandan genocide and the timespan of these intense killings was five times that in Rwanda (April-mid-July 1994). After September 1943, the survival curves show a smooth decrease in probability of survival, resulting in similar cumulative proportions surviving WWII for Jewish men (survival probability: 0.281; 95\%CI $0.278-$ 0.285 ) and women (survival probability: 0.283 ; $95 \% \mathrm{CI} 0.279-$ 0.287 ) from the Netherlands. Some of these Jews survived Nazi camps such as Auschwitz, Bergen-Belsen or Theresienstadt while others survived by being exempted from deportation and/or by hiding, fleeing or reclassification of their Jewish status.

\section{PROFILES OF GENOCIDE-RELATED DEATHS}

The survival curves of these cases indicate different epidemiological profiles of genocide-related deaths. The mortality rate and survival curve for Rwanda indicate an intense and rapid genocide. The mortality rate for the Nazi killings of Jews in four camps and during shootings might indicate a less intense but longer genocide. The survival curve shows two 


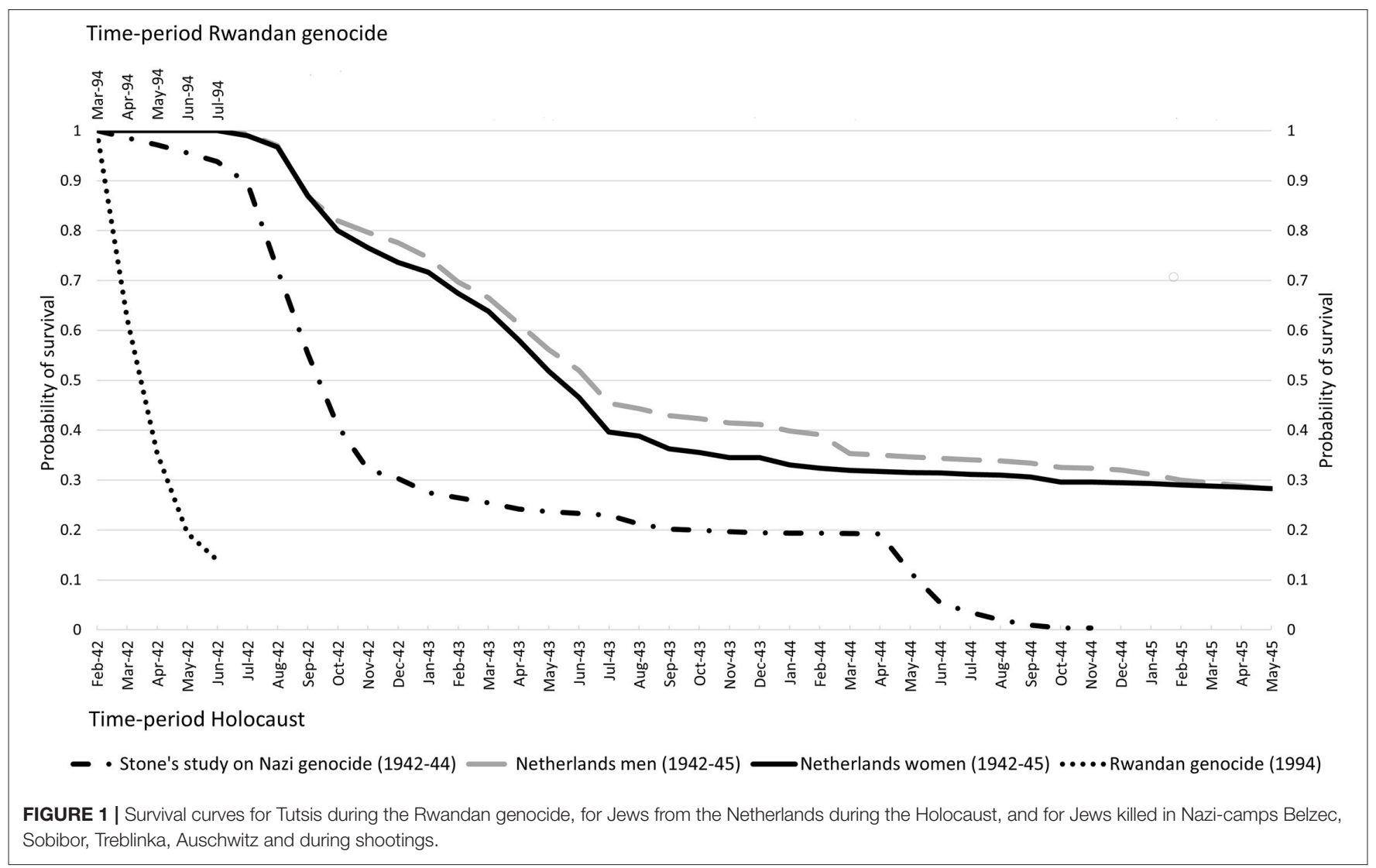

rapid and intense periods of killings with a long period of stable survival probabilities in-between. Survival curves for Jewish men and women from the Netherlands indicate a smoother but also a longer killing process with a long tail of slightly decreasing survival rates. The higher survival probabilities for men till March 1944 and the drop in these probabilities thereafter might suggest men were more often selected for work when arriving at Nazi camps but these selections might not have been protective since men's survival rate equals that for women in the end (10).

The importance of epidemiological methods in natural disaster to identify determinants of mortality and in medical assessment of refugees fleeing mass killings was recognized in the 1970s and 1980s (13). Thereafter, epidemiologic methods were widely applied during humanitarian responses to the subsequent wave of African famines and postcolonial civil wars in the 1980s enabling health analysts to describe how mortality and morbidity differed across population groups and over time, providing crucial insights for improving response and preparedness (13). While in some other recent epidemiological contributions the emphasis is on data collection (14-16), this Opinion article focused on the use of a few measures to analyse the available data and thereby adding to the Haddon matrix (17) adapted for an epidemiological study of genocide by Adler et al. (18). Applying epidemiological measures, even with crude mortality data, might result in better or earlier identification or understanding of genocide-related death during potential future and current or imminent genocides such as those against Yazidis in Iraq (19),
Rohingya Muslims in Myanmar (20), and Uyghurs and other Turkic Muslims in Northwest China (21), or the extreme sectarian violence between the pro-Muslim coalition Seleka and the pro-Christian movement Anti-Balaka in Central African Republic (22).

\section{DISCUSSION}

Tam et al. plead in their editorial "Epidemiology in conflictA call to arms" for more structured research and reasoned discussion on wars' impact on the public health and possible interventions in future conflicts (23). Within the field of epidemiology, population and public health studies growing attention is given to deaths and sufferings related to homicide (24-26), domestic violence $(27,28)$, suicide $(29,30)$, and armed conflict (31-34); only a few epidemiological studies focused on genocide $(10,35,36)$. This limited attention might be due to poorer data availability and quality. However, more data have become available over the past decades on, for example, the Holocaust.

Social science and historical studies focus mainly on causes of genocide, answering questions on "what," "why," and "how" it happened. Epidemiology, population, and public health studies should articulate the consequences of genocide, answering question on "who" became, "when," and "where" victim. Applying epidemiological methods could result in better understanding of genocide-related deaths in the past while it also 
provides better opportunities for comparison of these deaths. This greater knowledge about historical genocide-related deaths might then contribute to the writing of national and local histories, and remembrance and commemoration by providing better context and patterns of victimization and killings. At the same time, it could contribute to reducing mortality in future genocide by providing data and quantitative information on death frequencies improving predictive and interventive models.

Quantifying Holocaust and other genocides using epidemiological measures not only contributes to our historical understanding of genocides, but also provides groundwork for the investigation of exposure to genocide on health and the intergenerational transmission of genociderelated trauma (37-41). Data such as the reported in this study can improve the precision of exposure definitions that use spatiotemporal information on the extent and severity of the exposure, which is especially valuable

\section{REFERENCES}

1. Krug EG, Mercy JA, Dahlberg LL, Zwi AB. The world report on violence and health. Lancet. (2002) 360:1083-8. doi: 10.1016/S0140-6736(02)11133-0

2. De Waal A, Hazlett C, Davenport C, Kennedy J. The epidemiology of lethal violence in Darfur: using micro-data to explore complex patterns of ongoing armed conflict. Soc Sci Med. (2014) 120:368-77. doi: 10.1016/j.socscimed.2013.12.035

3. Degomme O, Guha-Sapir D. Patterns of mortality rates in Darfur conflict. Lancet. (2010) 375:294-300. doi: 10.1016/S0140-6736(09)61967-X

4. Spiegel PB, Salama P. War and mortality in Kosovo, 199899: an epidemiological testimony. Lancet. (2000) 355:2204-9. doi: 10.1016/S0140-6736(00)02404-1

5. Ratner SR, Abrams JS. Accountability for Human Rights Atrocities in InterNational Law: Beyond the Nuremberg Legacy. Oxford: Oxford University Press (2001).

6. Jones A. Genocide: A Comprehensive Introduction. London; New York, NY: Routledge (2016). doi: 10.4324/9781315725390

7. Prunier G. The Rwanda Crisis: History of a Genocide. New York, NY: Columbia University Press (1995).

8. Stone L. Quantifying the holocaust: hyperintense kill rates during the nazi genocide. Sci Adv. (2019) 5:eaau7292. doi: 10.1126/sciadv.aau7292

9. Tissot R. Beyond the "Numbers game": reassessing human losses in rwanda during the 1990s. J Genocide Res. (2020) 22:116-24. doi: 10.1080/14623528.2019.1703250

10. Tammes P. Associating locality-level characteristics with surviving the holocaust: a multilevel approach to the odds of being deported and to risk of death among jews living in Dutch municipalities. Am J Epidemiol. (2019) 188:896-906. doi: 10.1093/aje/kwz015

11. Greenland S, Rothman KJ. Measures of occurrence. In: Rothman KJ, Greenland S, Lash TL, editors. Modern Epidemiology. Philadelphia, PA: Wolters Kluwer Health; Lippincott Williams \& Wilkins (2008).

12. Suissa S. Immortal time bias in pharmacoepidemiology. Am J Epidemiol. (2008) 167:492-9. doi: 10.1093/aje/kwm324

13. Leaning J, Guha-Sapir D. Natural disasters, armed conflict, and public health. N Engl J Med. (2013) 369:1836-42. doi: 10.1056/NEJMra1109877

14. Checchi F, Warsame A, Treacy-Wong V, Polonsky J, Van Ommeren M, Prudhon C. Public health information in crisis-affected populations: a review of methods and their use for advocacy and action. Lancet. (2017) 390:2297313. doi: 10.1016/S0140-6736(17)30702-X

15. Rasmussen SA, Goodman RA. The CDC Field Epidemiology Manual. New York, NY: Oxford University Press (2018). doi: 10.1093/oso/97801909336 92.001 .0001 when individual-level data about the exposure status are not available.

Expanding our understanding of genocide-related deaths in the past, trying to prevent or reduce genocide-related deaths in the future, and improving health conditions of survivors and their offspring require input from different fields including epidemiology, population and public health studies.

\section{AUTHOR CONTRIBUTIONS}

The author confirms being the sole contributor of this work and has approved it for publication.

\section{ACKNOWLEDGMENTS}

The author would like to thank Gene Feder for comments on an earlier draft.
16. Seybolt TB, Aronson JD, Fischhoff B. Counting Civilian Casualties: An Introduction to Recording and Estimating Nonmilitary Deaths in Conflict. New York, NY: Oxford University Press (2013). doi: 10.1093/acprof:oso/9780199977307.001.0001

17. Haddon W Jr. Advances in the epidemiology of injuries as a basis for public policy. Public Health Rep. (1980) 95:411-21.

18. Adler RN, Smith J, Fishman P, Larson EB. To prevent, react, and rebuild: health research and the prevention of genocide. Health Serv Res. (2004) 39:2027-51. doi: 10.1111/j.1475-6773.2004.00331.x

19. Cetorelli V, Sasson I, Shabila N, Burnham G. Mortality and kidnapping estimates for the Yazidi population in the area of mount Sinjar, Iraq, in august 2014: a retrospective household survey. PLoS Med. (2017) 14:e1002297. doi: 10.1371/journal.pmed.1002297

20. Parmar PK, Leigh J, Venters H, Nelson T, Group PRS. Violence and mortality in the Northern Rakhine State of Myanmar, 2017: results of a quantitative survey of surviving community leaders in Bangladesh. Lancet Planet Health. (2019) 3:e144-e53. doi: 10.1016/S2542-5196(19)30037-3

21. Smith Finley J. Why scholars and activists increasingly fear a Uyghur genocide in Xinjiang. J Genocide Res. (2021) 23:348-70. doi: 10.1080/14623528.2020.1848109

22. Human Rights Watch. Central African Republic: Muslims Forced to Flee. Christian Militias Unleash Waves of Targeted Violence. New York, NY: Human Rights Watch (2014).

23. Tam CC, Lopman BA, Bornemisza O, Sondorp E. Epidemiology in conflict-a call to arms. Emerg Themes Epidemiol. (2004) 1:1-5. doi: 10.1186/1742-7622-1-5

24. Brentlinger PE, Hernán MA. Armed conflict and poverty in Central America: the convergence of epidemiology and human rights advocacy. Epidemiology. (2007) 18:673-7. doi: 10.1097/EDE.0b013e3181570c24

25. Krieger N, Chen JT, Waterman PD, Kiang MV, Feldman J. Police killings and police deaths are public health data and can be counted. PLoS Med. (2015) 12:e1001915. doi: 10.1371/journal.pmed.1001915

26. García J, Aburto JM. The impact of violence on Venezuelan life expectancy and lifespan inequality. Int J Epidemiol. (2019) 48:1593-601. doi: 10.1093/ije/dyz072

27. Feder G, Davies RA, Baird K, Dunne D, Eldridge S, Griffiths C, et al. Identification and referral to improve safety (IRIS) of women experiencing domestic violence with a primary care training and support programme: a cluster randomised controlled trial. Lancet. (2011) 378:178895. doi: 10.1016/S0140-6736(11)61179-3

28. Reis BY, Kohane IS, Mandl KD. Longitudinal histories as predictors of future diagnoses of domestic abuse: modelling study. BMJ. (2009) 339:b3677. doi: 10.1136/bmj.b3677 
29. Knipe D, Metcalfe C, Hawton K, Pearson M, Dawson A, Jayamanne $\mathrm{S}$, et al. Risk of suicide and repeat self-harm after hospital attendance for non-fatal self-harm in Sri Lanka: a cohort study. Lancet Psychiatry. (2019) 6:659-66. doi: 10.1016/S2215-0366(19) 30214-7

30. Phillips JA. A changing epidemiology of suicide? The influence of birth cohorts on suicide rates in the United States. Soc Sci Med. (2014) 114:151-60. doi: 10.1016/j.socscimed.2014. 05.038

31. Guha-Sapir D, van Panhuis WG. Conflict-related mortality: an analysis of 37 datasets. Disasters. (2004) 28:418-28. doi: 10.1111/j.0361-3666.2004. 00267.x

32. Guha-Sapir D, Rodriguez-Llanes JM, Hicks MH, Donneau A-F, Coutts A, Lillywhite L, et al. Civilian deaths from weapons used in the Syrian conflict. BMJ. (2015) 351:h4736. doi: 10.1136/bmj.h4736

33. Iraq Family Health Survey Study Group. Violence-related mortality in Iraq from 2002 to 2006. N Engl J Med. (2008) 358:484-93. doi: 10.1056/NEJMsa0707782

34. Grein T, Checchi F, Escribè JM, Tamrat A, Karunakara U, Stokes C, et al. Mortality among displaced former UNITA members and their families in Angola: a retrospective cluster survey. BMJ. (2003) 327:650. doi: 10.1136/bmj.327.7416.650

35. Tammes P. Survival of jews during the Holocaust: the importance of different types of social resources. Int J Epidemiol. (2007) 36:330-5. doi: 10.1093/ije/dym006

36. Maxwell A, Ross AH. Epidemiology of genocide: an example from the former Yugoslavia. For Sci Policy Manag Int J. (2011) 2:94-102. doi: 10.1080/19409044.2011.604378

37. Youssim I, Gorfine M, Calderon-Margalit R, Manor O, Paltiel O, Siscovick DS, et al. Holocaust experience and mortality patterns: 4-decade followup in a population-based cohort. Am J Epidemiol. (2021) 190:1541-9. doi: 10.1093/aje/kwab021
38. Rieder H, Elbert T. Rwanda-lasting imprints of a genocide: trauma, mental health and psychosocial conditions in survivors, former prisoners and their children. Conflict Health. (2013) 7:1-13. doi: 10.1186/1752-1505-7-6

39. Rubanzana W, Hedt-Gauthier BL, Ntaganira J, Freeman MD. Exposure to genocide and risk of suicide in Rwanda: a population-based case-control study. Epidemiol Commun Health. (2015) 69:117-22. doi: 10.1136/jech-2014-204307

40. Lipsicas CB, Levav I, Levine SZ. Holocaust exposure and subsequent suicide risk: a population-based study. Soc Psychiatry Psychiatr Epidemiol. (2017) 52:311-7. doi: 10.1007/s00127-016-1323-3

41. Fund N, Ash N, Porath A, Shalev V, Koren G. Comparison of mortality and comorbidity rates between Holocaust survivors and individuals in the general population in Israel. JAMA Netw Open. (2019) 2:e186643. doi: 10.1001/jamanetworkopen.2018.6643

Conflict of Interest: The author declares that the research was conducted in the absence of any commercial or financial relationships that could be construed as a potential conflict of interest.

Publisher's Note: All claims expressed in this article are solely those of the authors and do not necessarily represent those of their affiliated organizations, or those of the publisher, the editors and the reviewers. Any product that may be evaluated in this article, or claim that may be made by its manufacturer, is not guaranteed or endorsed by the publisher.

Copyright (C) 2022 Tammes. This is an open-access article distributed under the terms of the Creative Commons Attribution License (CC BY). The use, distribution or reproduction in other forums is permitted, provided the original author(s) and the copyright owner(s) are credited and that the original publication in this journal is cited, in accordance with accepted academic practice. No use, distribution or reproduction is permitted which does not comply with these terms. 